\title{
Regeneration, growth of Hill Sal and plant diversity in Community Forest: A case study from Pragatisil Community Forest in Kaski District, Western Nepal
}

\author{
B. K. Paudyal ${ }^{1}$
}

\begin{abstract}
The study was conducted in the Pragatisil Community Forest, Kaski District, Nepal in 2012 to assess the regeneration status of Sal (Shorea robusta) seedlings, its growth and plant diversity. A plot size of $25 \mathrm{~m} \times 20 \mathrm{~m}$ was employed for trees, $10 \mathrm{~m}$ $\times 10 \mathrm{~m}$ for poles and $5 \mathrm{~m} \times 5 \mathrm{~m}$ for regeneration. The growth parameters measured were $\mathrm{dbh}$ and height. A factorial arrangement of treatments was employed; the treatments being slope and aspect. The results showed that there was significant $(p \leq 0.05)$ effect of slope on $d b h$ and basal area whereas there was no effect of aspect on growth parameters measured in the Pragatisil Community Forest. The regeneration of Sal was satisfactory $(6,126$ seedlings/ha), and there were 32 plant species in this forest. As there was higher basal area per ha in the Pragatisil Community Forest, it is recommended to have thinning of $40 \%$ of basal area for enhancing growth of remaining stems.
\end{abstract}

Key words: Thinning, basal area, regeneration, diversity, structure

$\mathrm{S}$ al (Shorea robusta) is one of the most important timber species of India and Nepal. The forest found in this region is basically moist Sal (Stainton, 1972; Shrestha, 1989). In Nepal, Sal occurs in the extended Gangetic belt, the Siwaliks and also at the foot-hills of the Himalayas. Sal forms dominant composition, usually greater in number ( 80 to $90 \%$ ) than all the rest put together. Sal Forests in Nepal cover one million ha, representing more than $16 \%$ of the total forest of the country (GoN, 1989).

Sal Forest is dominant in the Bhabar Zone, except in the areas of very high rainfall, where it is replaced by mixed forest. It also covers most of the Siwalik Hills, and the duns between them. The maximum upper limit for its occurrence is 1,500 $\mathrm{m}$, but it is not common above $1,000 \mathrm{~m}$ (Jackson, 1994). Sal forms extensive forests and is highly gregarious. When other factors are favourable, the upper limit of Sal is probably regulated to a greater extent by frost. In excessively dry localities, such as on southern aspects, it gives way to more xerophytic species and in waterlogged areas, it is unable to compete with evergreen species.

Natural regeneration is adversely affected in moist Siwalik Sal Forests because of external factors such as extensive lopping and grazing. The invasion of weeds and climbers takes place due to excessive opening of canopy by lopping. Fire is another problem in this region due to topography and dry layer of fallen leaves. The regeneration of Sal in moist Bhabar natural forest is really a problem. However, this is not the case for community forests as they are well protected from fire, grazing and lopping activities.

The livelihood of rural people is very much dependent on forest products such as timber, fuel wood, fodder and small poles. Sal is the most important tree species in the Terai and also in the Mid-hills. It has a great potential to contribute to poverty alleviation by providing multiple uses. Forest Management in Nepal has to address this issue properly. For estimating sustainable future harvests from a given forest area in reliable manner, growth and yield models are prerequisite.

Shrestha (1992), on his report on Sal regeneration, has stated that Sal regeneration is prolific wherever openings are made and protected, but protection of natural regeneration is more difficult than protection of plantations. A detailed information on Sal in India is provided by Joshi (1986). 
Skarner (1995) has highlighted on research on Sal Forest management in Nepal. The author has reported on works by the Finnish International Development Agency (FINNIDA) aided Forest Management and Utilization Development Project (FMUDP) on Sal. The management trials by the FMUDP using large regeneration openings in natural forest have shown very promising results. The most obvious needs of forest products for rural people are fuelwood, fodder and timber. Sal can serve these multiple uses. The multiple use management concept can be applied for Sal in community forests. However, there is a need of growth studies in Sal Forest, especially for hills as most of the works have been done for the plains. Some works on growth of tree species have been published (Lamichaney, 1982). Korhonen et al. (1991) have reported on the diameter growth models for the forests of the Kapilvastu District to be used in the national forest inventory. The growth and yield models for uniform Sal Forest in the Bhabar-Terai in Nepal have been described by Rautianen (1995). However, research on Sal Forest management is relatively recent in Nepal and the growth and yield of this species also remain insufficiently studied. Rai et al. (1999) have highlighted on the ecology and growth of Sal in Central Nepal. Thus, this study was an attempt to assess regeneration, plant diversity and growth of hill Sal in community forests.

\section{Materials and methods}

\section{Site selection}

The study was conducted in the Pragatisil Community Forest of Kaski District. The district falls under the Western Development Region of Nepal.

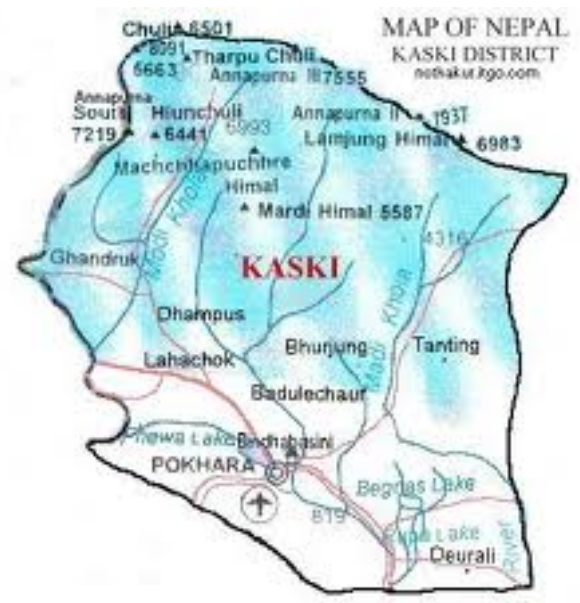

Fig.1: Map of study site
The site selection in the Mid-hills in Kaski District (Fig. 1) was done in consultation with forestry personnels from Western Regional Forest Directorate, Pokhara and District Forest Office Kaski, Pokhara. Potential sites in the region and in the Kaski District were explored to match the research objectives. After careful study on all potential sites, the Pragatisil Community Forest at Tallo Gagan Gaunda in Kaski District was selected for the purpose.

\section{Pragatisil Community Forest, Kaski}

This Community Forest (CF) is situated in Ward No. 13 Lekhnath Municipality, Kaski District. The total area of the CF is 57.74 ha; the total number of household being 341. The forest was handed over as CF to the User Group in 1993, and the present Community Forestry Operational Plan (CFOP) was renewed in 2002 and 2007. Before being handed over as $\mathrm{CF}$, the forest was protected and used by the local people since 1977. The elevation of the area is $827 \mathrm{~m}$ from mean sea level. The mean daily temperature is $20.2^{\circ} \mathrm{C}$, and the yearly precipitation is $3,388 \mathrm{~mm}$ which is nearly $50 \mathrm{~km}$ from the Lumle Meteorological Station.

The CF has three main divisions

1. Kamardhik Forest: This forest is dominated by Sal as the main species with few Chilaune (Schima wallichii). The area of this forest is 21.87 ha, and is now 30-year-old.

2. Rani Ban: The area of this forest is 5.20 ha. In 1976, Sissoo (Dalbergia sissoo) and Khair (Acacia catechu) were planted, and there is abundant regeneration of Khair. Previously, this area was full of natural Khair Forest.

3. Satpatre Ban: The area of this forest is 11.25 ha. In 1976, Sissoo and Khair were planted, and now, there is good regeneration of Khair. Previously, this area was also full of natural Khair Forest.

\section{Experimental layout}

While establishing the plots, some reference points near the forest boundary were taken, and systematic sampling was carried out, the plot to plot distance was generally $40 \mathrm{~m}$. There were, altogether, 20 plots established in Kamardhik Forest.

The treatments were aspect and slope each at two levels $(2 \times 2)$. The aspects of the terminals 
were east and west with the slope ranging from $25^{\circ}$ to $40^{\circ}$. Thus, there were four treatments and five replications with 10 plots each with $25 \mathrm{~m} \times 20 \mathrm{~m}$ size established in the east and 10 plots in the west. All the trees having over $30 \mathrm{~cm} \mathrm{DBH}$ were measured. Within every $25 \mathrm{~m} \times 20 \mathrm{~m}$ plots, a $10 \mathrm{~m} \times 10 \mathrm{~m}$ sub-plot was established for measuring poles (DBH: 10-29.9 $\mathrm{cm}$ ) and within this, a $5 \mathrm{~m} \times 5 \mathrm{~m}$ subplot was established for regeneration of Sal and other plant species. Within $5 \mathrm{~m} \times 5 \mathrm{~m}$ subplot, saplings $(>4 \mathrm{~cm}<10 \mathrm{~cm}$ diameter) were measured for diameter and height. Seedlings less than $4 \mathrm{~cm}$ diameter were recorded for regeneration.

\section{Data collection}

The growth parameters collected include DBHs of all the trees, heights of six trees per plot, regeneration of Sal and density of other associated plant species. DBH was measured using Diameter Tape and the height with the help of Abney's Level. The heights of six trees $(>10$ $\mathrm{cm} \mathrm{DBH}$ ) representing all diameter classes in the plot were measured.

\section{Data analysis}

The growth parameters were analyzed using MSExcel and SPSS. ANOVA was used to assess the effect of slope and aspect on the growth parameters. Index of dominance, Simpson's Diversity Index and Shannon Index were calculated. For calculating density of Sal and other plant species, the total number of each species in all the plots were determined, and was converted into plants per ha.

\section{Results and discussion}

\section{Diameter, height and volume growth}

The effect of slope and aspect on growth parameters are shown in table 1. The results showed that slope had significant $(\mathrm{p} \leq 0.05)$ effect on DBH and basal area only. There was no significant $(p \leq 0.05)$ effect of aspect on growth parameters. Table 2 indicates that the forest is predominantly a pole-sized one. The higher basal area per ha $\left(48.67 \mathrm{~m}^{2}\right)$ indicates high stocking per ha and which in turn indicates a need for thinning the stand down to $40 \%$ basal area. The regeneration of Sal was found to be 6,126 seedlings/ha which can be considered as satisfactory. The Mean Annual Increment (MAI) for DBH and height was
$0.6 \mathrm{~cm}$ and $0.6 \mathrm{~m}$ respectively. This was based on the assumption by the community people that the average age of the stand was 30 years. Similarly, the MAI in terms of volume was $6.71 \mathrm{~m}^{3} / \mathrm{ha}$.

Table 1: Effects of slope and aspect on growth parameters

A. Effects of slope

\begin{tabular}{|c|c|c|c|}
\hline $\begin{array}{c}\text { Growth } \\
\text { Parameters }\end{array}$ & Number & F-Value & Significance \\
\hline $\mathrm{DBH}(\mathrm{cm})$ & 325 & 3.184 & $0.005 \mathrm{xx}$ \\
\hline $\mathrm{Ht}(\mathrm{m})$ & 113 & 2.004 & $0.071 \mathrm{~ns}$ \\
\hline B.A. $\left(\mathrm{m}^{2} / \mathrm{ha}\right)$ & 325 & 3.405 & $0.005 \mathrm{xx}$ \\
\hline Volume $\left(\mathrm{m}^{3} / \mathrm{ha}\right)$ & 113 & 0.317 & $0.729 \mathrm{~ns}$ \\
\hline $\begin{array}{l}\text { Regeneration of } \\
\text { Sal (seedlings } \\
\text { number/ha) }\end{array}$ & 291 & 0.066 & $0.936 \mathrm{~ns}$ \\
\hline
\end{tabular}

ns: not significant $x x$ : significant $(p \leq 0.05)$

B. Effects of aspect

\begin{tabular}{lrrr}
\hline \multicolumn{1}{c}{$\begin{array}{c}\text { Growth } \\
\text { Parameters }\end{array}$} & Number & F-Value & Significance \\
\hline $\mathrm{DBH}(\mathrm{cm})$ & 325 & 1.302 & $0.274 \mathrm{~ns}$ \\
$\mathrm{Ht}(\mathrm{m})$ & 113 & 0.002 & $0.998 \mathrm{~ns}$ \\
B.A. $\left(\mathrm{m}^{2} / \mathrm{ha}\right)$ & 325 & 0.984 & $0.321 \mathrm{~ns}$ \\
$\begin{array}{l}\text { Volume }\left(\mathrm{m}^{3} / \mathrm{ha}\right) \\
\begin{array}{l}\text { Regeneration of } \\
\text { Sal (seedlings } \\
\text { number/ha) }\end{array}\end{array}$ & 113 & 0.258 & $0.812 \mathrm{~ns}$ \\
\hline
\end{tabular}

ns: not significant $x x$ : significant $(\mathrm{p} \leq 0.05)$

For assessment of the growth of Sal in the Pragatisil Community Forest, the results of 2007 when the CFOP, 2002 was renewed and those of the present study conducted in 2012 need to be compared. The Operational Plan, 2002 indicated that there was a stand with an average DBH of $13.95 \mathrm{~cm}$ whereas the present study provided a result of the stand with an average DBH of 18.05 $\mathrm{cm}$. These two results may not be comparable as the number of plots were different. However, the results indicated that there was roughly $4 \mathrm{~cm} \mathrm{DBH}$ increment during the last five years. This is for the whole stand, irrespective of the diameter size. Similar is the case in the case of height increment too. There was an increment of nearly $4 \mathrm{~m}$ height (from $13.42 \mathrm{~m}$ mentioned in the Operational Plan of 2007 as compared to $17.20 \mathrm{~m}$ in the present study) during five years interval. In the case of volume growth, Amatya and Amatya (1995) observed the MAI of $9.7 \mathrm{~m}^{3} / \mathrm{ha}$ in 5 to 
9 years old Sal Forest in three protected areas: Sagarmatha National Park, Chitwan National Park and Banke National Park. The present study indicated the MAI in terms of volume as $6.71 \mathrm{~m}^{3} / \mathrm{ha}$ in the Pragatisil Community Forest. This gives an indication that as the stand advances, the MAI in terms of volume slows down. Skarner (1995) reports that due to annual die-back process in Sal seedling, seedling height may reach just $1 \mathrm{~m}$ after 10 years and $2 \mathrm{~m}$ only after 25 years. Thus, at the initial phase, slow growth seems to be a tendency in Sal Forest. The low figure (11) for saplings $(>4<10 \mathrm{~cm}$ diameter) in the Pragatisil Community Forest in future.

\section{Density and plant diversity}

The results showed that the index of dominance was 0.41 (Sal representing $41 \%$ in the stand). The Simpson's Diversity Index was 0.59 and Shannon Index $(\mathrm{H})$ was 8.64 (Table 2) showing higher diversity in the forest. Pandey and Shukla (2003) recorded a total of 208 plant species representing 165 genera and 72 families in a Sal Forest in Gorakhpur, India. Similarly, Timilsina et al. (2007) reported, altogether, 131 species in the Sal Forest of the Western Terai, Nepal. Shankar (2001) in a report from Sal-dominated forest in the Eastern Himalayan lowlands of Mahanand Sanctuary, Darjeeling, India observed 156 species in the area. In the two Sal Forests in Western Nepal, Gautam (2001) observed 94 and 120 plant species. Similarly, according to Shrestha (2005), Sal was found to be the dominant tree species with 909 trees/ha in a community forest of Gorkha District and in Dhading District, Sal was found to be mixed with other species. Paudyal (2011) observed 58 plant species in the Sal-dominated Lamindanda Community Forest of Tanahu District. The regeneration of Sal was found to be satisfactory with 6,126 seedlings/ha. The results (Table 3) showed that in the Pragatisil CF, Sal with higher density 291 stems/ha was dominant. There were 32 plant species observed in the area, which showed higher species diversity in hill Sal forest.

\section{Structure of forest}

In the present study, the structure of the forest in the Pragatisil Forest showed (Table 4) that it was mainly dominated by pole-sized trees. The number of trees $(>30 \mathrm{~cm} \mathrm{DBH})$ was thus 12 trees/ ha only whereas in the case of poles, it was 1595 trees/ha. According to CFOP 2007 of the CF, there were 26 trees/ha and 831 poles/ha. These two figures could not be compared directly as the size and the location of the plots were not the same. However, the number of trees in the present study was found to be in increasing order but in the case of poles, it is in decreasing order. Thus, it may be assumed that during the period, many pole-sized trees might have turned into trees. Pande (1999) has reported that not only disturbance and stand age, but also the compactness of the stand due to the presence of old and big trees affect upon the regeneration of Sal in the moist areas.

Bellingaham and Tanner (2000), in a study in tropical montane forest of Jamaica, observed that mortality was higher on northern aspect while growth and recruitment rates were not

Table 2: Summary statistics of Kamardhik Forest

\begin{tabular}{|c|c|c|c|c|c|c|c|}
\hline $\begin{array}{c}\text { Growth } \\
\text { Parameters }\end{array}$ & No. & Range & Min. & Max. & Mean & Sum & MSE \\
\hline $\mathrm{DBH}(\mathrm{cm})$ & 325 & 52.00 & 4.30 & 56.30 & 18.05 & - & 0.3351 \\
\hline Height (m) & 113 & 35.70 & 5.60 & 41.30 & 17.20 & - & 0.4578 \\
\hline B.A.(m²/ha) & 325 & 1.30 & 0.01 & 1.31 & 0.1497 & 48.67 & 0.0064 \\
\hline Volume(m³/ha) & 113 & 26.90 & 0.14 & 27.04 & 1.78 & 201.30 & 0.2585 \\
\hline $\begin{array}{l}\text { Regeneration } \\
\text { of Sal(seedlings } \\
\text { number/ha) }\end{array}$ & 291 & & & & & 6,126 & \\
\hline $\begin{array}{l}\text { Spp. Density } \\
\text { (stem number/ } \\
\text { ha) }\end{array}$ & 703 & & & & & & \\
\hline
\end{tabular}

Note: Index of dominance-0.41, Simpson's Diversity Index-0.59, Shannon Index-8.64 
Table 3: Density of plant species

\begin{tabular}{|c|c|c|c|c|}
\hline S.N. & Local Name & Botanical Name & No. of Species/ha & Regneration/ha \\
\hline 1. & Sal & Shorea robusta $(\mathrm{T})$ & 291 & 6126 \\
\hline 2. & Latikath & Cornus oblongum $(\mathrm{T})$ & 6 & 126 \\
\hline 3. & Chilaune & Schima Wallichii $(\mathrm{T})$ & 39 & 821 \\
\hline 4. & Bhant & ClerodendronViscosum (S) & 9 & 189 \\
\hline 5. & Sindure & Mallotus phillippinensis (T) & 7 & 147 \\
\hline 6. & Gindari & Premna antegrefolia $(\mathrm{T})$ & 7 & 147 \\
\hline 7 & Kantkari & Solanum xanthocarpum $(\mathrm{H})$ & 1 & 21 \\
\hline 8. & Botdhairo & Lagerstroemia parviflora $(\mathrm{T})$ & 7 & 147 \\
\hline 9. & Khirro & Sapium insigne $(\mathrm{T})$ & 5 & 105 \\
\hline 10. & Ankhatare & Trichillia connaroides $(\mathrm{T})$ & 2 & 42 \\
\hline 11. & Nilkanda & Duranta repens $(\mathrm{S})$ & 2 & 42 \\
\hline 12. & Bilaune & Maesachisia $(\mathrm{T})$ & 3 & 63 \\
\hline 13. & Jamun & Syzygium cumini $(\mathrm{T})$ & 9 & 189 \\
\hline 14. & Amala & Phyllanthus emblica $(\mathrm{T})$ & 1 & 21 \\
\hline 15. & Areli & Hypericum cordifolium (S) & 2 & 42 \\
\hline 16. & Arkhu & Acacia intsia $(\mathrm{T})$ & 6 & 126 \\
\hline 17. & Nundhiki & Osyris santalaceae $(\mathrm{T})$ & 13 & 274 \\
\hline 18. & Rudilo & Pogostemon benghalensis (S) & 2 & 42 \\
\hline 19. & Kharseto & Phyllanthus parvifolius (S) & 1 & 21 \\
\hline 20. & Tiju & Picrasama javanica $(\mathrm{T})$ & 2 & 42 \\
\hline 21. & Archal & Anfidesma spp. (S) & 15 & 316 \\
\hline \multirow[t]{3}{*}{22.} & Githa & Dioscorea bulbifera (C) & 110 & 2316 \\
\hline & $\begin{array}{l}\text { Unidentified plant } \\
\text { species (10) }\end{array}$ & & 163 & 3,438 \\
\hline & Total & & 703 & 14,797 \\
\hline
\end{tabular}

Note: T-tree, S-shrub, C-climber

Table 4: Structure of the forest stand

\begin{tabular}{rr}
\hline DBH class $(\mathrm{cm})$ & Number of stems/ha \\
\hline $0-10^{*}$ & 58 \\
$10-20$ & 1153 \\
$20-30$ & 442 \\
$30-40$ & 10 \\
$40-50$ & 1 \\
$50-60$ & 1 \\
\hline
\end{tabular}

Note-*signifies saplings greater than $4 \mathrm{~cm}$ diameter significantly different among positions (north, south and hill ridgetop). The effect of slope on diameter and height growth was shown by Robert and Moravie (2003) whereas there was no effect of slope and aspect on ground cover (Sabhasri and Ferrel 1960). Basnet (1992) reported that trees were significantly related to topographical variables. Similarly, according to Yang et al. (2006) temperature, aspect, precipitation and soil thickness all significantly influence forest growing stock.

The present study had some limitations. The study was carried out only for one time, and as such, the increment part could not be assessed. However, the information can give an idea on the effect of slope and aspect the growth of Sal Forest. The soil properties on various slopes and aspects might also have effect on growth status. This factor was not considered in the present study. 


\section{Conclusion}

In the Pragatisil $\mathrm{CF}$, the slope had significant $(p \leq 0.05)$ effect on DBH and basal area whereas aspect did not have any significant effect on the growth parameters.

\section{References}

Amatya, S. M. and Amatya, D. B. 1995. Plantation vs protection: the choice is yours. Banko Janakari 5 (1): 31-35.

Basnet, K. 1992. Effect of topography on the pattern of trees in Tabonuco (Dacryodes excelsa) dominated rain forest of Puerto Rico. Biotropica 24 (1): 31-42.

Bellingham, P. J. and Tanner, E. V. J. 2000. The influence of topography on tree growth, mortality, and recruitment in a tropical montane forest. Biotropica 32 (3): 378-384.

CFOP. 2002. Pragatisil Community Forest Operational Plan, Kaski, Nepal.

CFOP. 2007. Pragatisil Community Forest Operational Plan, Kaski, Nepal.

Gautam, K. H. 2001. Lopping Regimes in Community Managed Sal (S. robusta) Forests of Nepal: Prospects for Multiple Product Silviculture for Community Forestry. Ph.D. dissertation, School of Forestry, University of Canterbury, Christchurch, New Zealand.

GoN. 1989. Master Plan for the Forestry Sector Nepal. Ministry of Forests and Soil Conservation, Kathmandu, Nepal.

Jackson, J. K. 1994. Manual of Afforestation in Nepal. 2nd edition. Forest Survey and Research Division, Babarmahal, Kathmandu, Nepal.

Joshi, H. B. 1986. Troup's Silviculture of Indian trees. Volume 11. Dipterocarpaceae. Dehradun, India.

Korhonen, K. T., Sharma, E. R. and Rajbhandari, M. D. 1991. Diameter Growth and Height Models for Forest Trees in Kapilbastu District. Mimeograph. Forest Survey and Statistics Division. Ministry of Forests and Soil Conservation.

Lamichaney, B. P. 1982. Growth and reproduction experiment in natural Sal (S. robusta) Forest, Ramnagar, Chitwan, Nepal. Nepal Forestry
Technical Bulletin 6: 23-24.

Pande, P. K. 1999. Comparative vegetation analysis of Sal Shorea robusta regeneration in relation to their disturbance magnitude in some Sal Forests. Tropical Ecology 241: 223-234.

Pande, S. K. and Shukla, R. P. 2003. Plant diversity in managed Sal Shorea robusta Gaertn. forests of Gorakhpur, India, species composition, regeneration and conservation. Biodiversity Conservation 12: 2295-2319.

Paudyal, B. K. 2011. Regeneration, plant diversity and growth of hill Sal (S. robusta) in community forests (A case study from Lamidanda Community Forest from Tanahu). Natural Resources Management: Reviews and Research in the Himalayan Watersheds (Special publication of NUFU HIMUNET project). Institute of Forestry. pp. 82-90.

Rai, S. N., Dutta, I. C., Haque, S., Khanal, B. B., Chaurasia, J. P. and Indu, I. P. 1999. "Ecology and growth of S. robusta in central Nepal" paper presented at Institute of Forestry, Pokhara, Nepal.

Rautiainen, O. 1995. Growth and Yield Models for Uniform Sal ( $S$. robusta) Forests in the Bhabar Terai in Nepal. FMUDP Technical Report No. 17. Department of Forest, National Forest Division, Kathmandu, Nepal.

Robert,A. and Moravie, M. A. 2003. Topographical variation and stand heterogenity in a wet evergreen forest of India. Journal of Tropical Ecology 19: 697-707.

Sabhasri, S. and Ferrel, W. K. 1960. Invasion of brush species into small stand openings in the Douglas-fir forests of the Willamette foothills. Northwest Science 4 (3): 77-88.

Shankar, U. 2001. A Case of High Tree Diversity in a Sal ( $S$. robusta) Dominated Lowland Forest of Eastern Himalaya: Floristic Composition, Regeneration and Conservation (www.ias.ac.in/currsci./oct102001/776.pdf).

Shrestha, B. B. 2005. Fuelwood harvest management and regeneration of two community forests in central Nepal. Himalayan Journal of Science. 3 (5): 75-80.

Shrestha, B. P. 1989. Forest Plants of Nepal. Educational Enterprises Pvt. Ltd., Kathmandu, Nepal. 
Shrestha, B. P. 1992. Evaluation of Sal (S. robusta), Sissoo (Dalbergia sissoo) Management in Nepal through Publications and Field Experience. Forest Management and Utilization Development Project. Technical Report No. 2, FMUPP, Kathmandu, Nepal.

Skarner, G. A. 1995. Research on Sal ( $\boldsymbol{S}$. robusta) Forest Management in Nepal. A Consultancy report for the Nepal-United Kingdom Forestry Research Project, Kathmandu, Nepal.
Stainton, J. D. A. 1972. Forests of Nepal. John Murray, London, UK.

Timilsina, N., Ross, M. S. and Heinen, J. T. 2007. A community analysis of Sal (S. robusta) in Western Terai of Nepal. Forest Ecology and Management 241 (1-3): 223-234.

Yang, Y. M., Li, F., Watanbe, Z., Zhang, J. and Zhai, Z. 2006. Factors affecting forest growth and possible effects of climate change in the Taihang mountains, northern China. Forestry 79 (1): 135-147. 